\title{
Identification of inappropriate prescribing in a Brazilian nursing home using STOPP/START screening tools and the Beers' Criteria
}

\author{
Mariana Martins Gonzaga Nascimento,2,", Andréia Queiroz Ribeiro³, Mariana Linhares Pereira ${ }^{1}$, \\ Adriana Cristina Soares ${ }^{1}$, Antônio Ignácio de Loyola Filho ${ }^{2}$, Carlos Alan Candido Dias-Junior ${ }^{1}$
}

\author{
${ }^{1}$ Pharmacy Faculty, Federal University of São João del-Rei, São João del-Rei, MG, Brazil, ${ }^{2}$ René Rachou \\ Reseach Center, Oswaldo Cruz Foundation, Belo Horizonte, MG, Brazil, ${ }^{3}$ Nutrition and Health, \\ Federal University of Viçosa, Viçosa, MG, Brazil
}

\begin{abstract}
The objective of this study was to determine the prevalence of Potentially Inappropriate Medication (PIM) use and associated factors, as well as the prevalence of Prescribing Omissions (PO). A cross-sectional study was conducted in a philanthropic Brazilian nursing home involving 46 individuals aged 60 years or older. The following information was collected from medical records and drug prescriptions: gender, age, health conditions and drugs used in the past thirty days. PIM and PO were identified according to the Beers' Criteria and the STOPP/START screening tools. Over one third (37\%) of the population used at least one PIM according to the Beers' Criteria $(\mathrm{n}=17)$ and $60.9 \%$ according to the STOPP tool. A significant association was found between polypharmacy (use of five or more drugs) and use of PIM according to the Beers' Criteria, but not according to the STOPP. Eight residents $(17.4 \%)$ were exposed to eight PO. This study allowed the diagnosis of a concerning drug utilization profile with use of a high number of PIMs. Thus, there is an evident need to implement strategies for improving geriatric prescription.
\end{abstract}

Uniterms: Pharmacoepidemiology. Pharmaceutical care. Elderly/inappropriate use of medicines. Medicines/inappropriate prescribing. Medicines/inappropriate use. Beers' Criteria.

O objetivo deste estudo foi determinar a prevalência de uso de medicamentos potencialmente inadequados (MPI) e fatores associados, bem como a prevalência de omissões farmacoterapêuticas (OF). Trata-se de um estudo transversal realizado em uma instituição filantrópica brasileira de longa permanência com 46 indivíduos com 60 anos ou mais. As seguintes informações foram coletadas a partir de prontuários e prescrições: sexo, idade, condições de saúde e medicamentos utilizados nos últimos trinta dias. MPI e OF foram identificados pelo Critério de Beers e as ferramentas de triagem STOPP/START. Mais de um terço $(37 \%)$ da população utilizou pelo menos, um MPI de acordo com os critérios de Beers $(\mathrm{n}=17)$ e $60.9 \%$ de acordo com a ferramenta STOPP. Associação estatisticamente significante foi detectada entre a polifarmácia (consumo de cinco ou mais medicamentos) e uso de MPI de acordo com os critérios de Beers, mas não de acordo com o STOPP. Oito residentes $(17,4 \%)$ foram expostos a oito OF. Este estudo permitiu o diagnóstico de um perfil de utilização de medicamentos preocupante com número elevado de utilização de MPI. Isso indica a necessidade de implementar estratégias para melhorar a qualidade da prescrição geriátrica.

Unitermos: Farmacoepidemiologia. Atenção farmacêutica. Idoso/uso inapropriado de medicamentos. Medicamentos/prescrição inadequada. Medicamentos/uso inapropriado. Critério de Beers.

*Correspondence: M. M. G. Nascimento. Centro de Pesquisa René Rachou. Avenida Augusto de Lima, 1.715, Barro Preto, 30190-002 - Belo Horizonte MG, Brasil. E-mail: marianamgn@yahoo.com.br 


\section{INTRODUCTION}

The aging process in developing countries has occurred at a fast pace, particularly in Brazil, where the number of elderly has increased from 3 to 20.5 million in the last 50 years (1960 to 2010) (IBGE, 2010).

Demographic changes in the Brazilian population have been accompanied by an epidemiological transition, which is characterized by a reduction in the incidence of infectious and parasitic diseases and a progressive increase in the occurrence of chronic diseases predominantly affecting the elderly population (Schramm et al., 2004). This health profile weakens and reduces the independence of the elderly population, generating a continuous and growing demand for multidisciplinary health care teams, hospitalizations, use of medications and even institutionalization (Berenstein, Wajnman, 2008).

In this scenario, the use of multiple medications encompasses risks and benefits. For this reason, the appropriateness of drugs prescription and use are important indicators for assessing the quality of health for the elderly.

The process of selecting drugs for the elderly should be made with caution, since the use of some active ingredients may present more risks than benefits in this age group (Hamilton, Gallagher, O'Mahony, 2009). Such medications are called Potentially Inappropriate Medications (PIM). The Beers' Criteria and the STOPP (Screening Tool of Older Persons' Potentially Inappropriate Prescriptions) are important references that list drug classes, specific medications and prescribing patterns that fit this category (Fick et al., 2003; O'Mahony et al., 2010). Moreover, the nonprescription of needed drugs, or Prescribing Omissions (PO), also represents an important problem that can be detected by the START (Screening Tool to Alert to Right Treatment): a list of prescription patterns that should be implemented when a specific diagnosis is detected (O'Mahony et al., 2010).

International studies show that the use of PIM and the occurrence of PO are associated with an increased risk of falls, fractures, postoperative confusion, gastrointestinal bleeding, constipation, worsening of congestive heart failure, depression and renal failure (Hamilton, Gallagher, O'Mahony, 2009). Consequently, the prescription of PIM has also been associated with increased mortality and hospitalization among the elderly (Hamilton, Gallagher, O’Mahony, 2009; Ruggiero et al., 2010).

However, many prescribers are unaware of these tools, and the identification of PIM use among the elderly has been internationally documented in nursing homes (NH) (Ruggiero et al., 2010; Gutiérrez-Rodríguez, LópezGaona, 2010; García-Gollarte et al., 2012) in hospitals
(Gallagher, O'Mahony, 2008; Nagendra Vishwas et al., 2012), emergency services (Dalleur et al., 2012) and the community (Cahir et al., 2010).

The use of PIM and the occurrence of PO are even more worrying when taking into consideration $\mathrm{NH}$ residents, since this population tends to have more debilitated health and functional status and uses more drugs (Braunseis et al., 2011). However, there are few studies investigating drug utilization in Brazilian NHs, and there are no studies applying the STOPP/START tool to assess geriatric prescription quality in Brazil.

The overall aim of this study was therefore to determine the health conditions and drug utilization patterns in the studied population, the prevalence of PIM use and associated factors, as well as the prevalence of PO.

\section{METHODS}

A cross-sectional observational study was conducted in a philanthropic NH located in the city of Divinopolis, Minas Gerais State, Brazil.

The eligible study population comprised all individuals aged 60 years or older (criteria for defining elderly subjects in developing countries), residing in the NH in September 2010.

The following information was collected from medical records and drug prescriptions: gender, age, health conditions and drugs used in the last thirty days.

Drugs prescribed were coded using the first and second level of the Anatomical Therapeutic Chemical (ATC) classification system (WHO, 2012). Polypharmacy was defined as the use of five or more drugs. PIM were identified according to the Beers' Criteria (independent / considering diagnosis or conditions) (Fick et al., 2003) and the Screening Tool for Older Persons' Prescriptions (STOPP) (O'Mahony et al., 2010). Identification of PIM according to the STOPP also took into consideration the data from previous prescriptions in order to define the period of utilization. POs were detected using the Screening Tool to Alert to Right Treatment (START) (O'Mahony et al., 2010).

The present study was conducted in compliance with the standards required by the Helsinki Declaration and its ethical approval was granted by the Research Ethics Committee of the Educational Foundation of Divinopolis (FUNEDI) of the State University of Minas Gerais (UEMG) in May 2010, under ethical statement no. $27 / 2010$.

\section{Statistical analysis}

A database to store the information gathered was 
created on EpiInfo 3.5.3. Data were primarily analyzed through descriptive statistics: frequency distribution, measures of central tendency (mean and median) and dispersion (range and standard deviation).

The association between sex, age groups (60-79 and $>79$ years) and polypharmacy and PIM prescription was assessed using bivariate analyses. Pearson's Chi-square test was performed for the comparison of proportions or Fisher's exact test when pertinent. The selected association measure was the odds ratio with $95 \%$ confidence interval, estimated by logistic regression. For median comparison, the Mann-Whitney test was used. A 5\% significance level was defined for all comparisons.

\section{RESULTS}

\section{Study sample demographics and health conditions}

All the elderly residents were included in the study $(\mathrm{n}=46)$. The detected mean \pm SD age was $80.5 \pm 8.5$ years and $61 \%$ of the elderly were female.

A total of 49 diagnoses were identified on the medical charts (mean $=1,1$, ranging from 0 to 2 ) and the most frequent were: Hypertension (17.4\%), Diabetes (15.2\%), Senile Dementia (9.8\%), Parkinson's Disease (9.8\%) and Bipolar Affective Disorder (9.8\%).

In total, $95.7 \%$ of the population under study used at least one drug $(n=44)$ and a total of 196 drugs was prescribed (mean $\pm \mathrm{SD}$ of $4.3 \pm 2.7$ ). Polypharmacy was prescribed to $38.6 \%$ of the residents $(n=17)$.
The most frequently prescribed medications belonged to the "Nervous System" anatomical group (34.7\%), followed by the "Cardiovascular System" (29.7\%) and "Alimentary Tract and Metabolism" (17,9\%). Taking into considerations the therapeutic classification, the "Psycholeptics" (14.8\%) and "Diuretics" (9.7\%) were the most prescribed group of drugs.

\section{Prevalence of PIM use}

Over one third (37\%) of the population used at least one PIM according to Beers' Criteria $(n=17)$. Twenty $(10.2 \%)$ out of the 196 prescribed drugs were classified as a PIM according to the Beers' Criteria - independent of diagnosis or conditions (Table I), and only one of these (diazepam prescribed to an elder with urinary incontinence) was simultaneously classified as a PIM considering diagnosis or conditions. Diazepam was also the most prescribed PIM among the residents (prescribed to nine of the residents) followed by immediate release nifedipine (three residents) and amitriptyline (two residents).

Taking the STOPP tool into consideration, the prevalence rate of PIM use among residents was $60.9 \%$. Among the medications consumed, 47 PIM were detected ( $24 \%$ of the drugs prescribed). Omeprazole (prescribed to $28.3 \%$ of the elderly; $n=13)$, Diazepam $(19.7 \%$; $n=9)$ and Haloperidol $(10.9 \% ; n=5)$ were the most frequently prescribed PIM (Table II). A statistically significant difference was found between the medians of number of PIM detected with the STOPP tool and the Beers' Criteria ( 0.0 vs. 1.0 drug, respectively; $p=0.006$ ).

TABLE I - Frequency of potentially inappropriate medication prescription according to the Beers' criteria

\begin{tabular}{|c|c|c|}
\hline Potentially Inappropriate Medication & $\begin{array}{c}\text { Absolute } \\
\text { Frequency (n) }\end{array}$ & $\begin{array}{c}\text { Relative } \\
\text { Frequency }(\%)\end{array}$ \\
\hline Diazepam - Prolonged sedation and increased risk of falls and fractures & 9 & 45.0 \\
\hline Nifedipine - Potential for hypotension and constipation & 3 & 15.0 \\
\hline Amitriptyline - Presents strong anticholinergic and sedation properties & 2 & 10.0 \\
\hline $\begin{array}{l}\text { Alprazolam (dose }>2 \mathrm{mg} \text { ) - Because of increased sensitivity to benzoadiazepines in } \\
\text { elderly patients, smaller doses may be effective as well as safer }\end{array}$ & 1 & 5.0 \\
\hline $\begin{array}{l}\text { Amiodarone - Associated with QT interval problems and risk of provoking torsades de } \\
\text { pointes. Lack of efficacy in older adults. }\end{array}$ & 1 & 5.0 \\
\hline $\begin{array}{l}\text { Digoxin (dose }>0.125 \mathrm{mg} \text { ) - Decreased renal clearance may lead to increased risk of } \\
\text { toxic effects }\end{array}$ & 1 & 5.0 \\
\hline Doxazosin - Potential for hypotension, dry mouth, and urinary problems & 1 & 5.0 \\
\hline Flurazepam - Prolonged sedation and increased risk of falls and fractures & 1 & 5.0 \\
\hline Promethazine - Presents potent anticholinergic properties. & 1 & 5.0 \\
\hline TOTAL & 20 & 100 \\
\hline
\end{tabular}




\section{Factors associated with PIM use}

There was no association between age groups or sex and use of PIM according to the Beers' Criteria ( $\mathrm{p}=0.220$ and 0.828 respectively) or the STOPP ( $\mathrm{p}=0.828$ and 0.979$)$. Polypharmacy was found to be associated with PIM identification according to the Beers' Criteria $(\mathrm{p}<0.05)$, but not according to the STOPP tool ( $\mathrm{p}=0.125)$ (Table III).

\section{Prevalence of PO}

With the application of the START tool, eight residents $(17.4 \%)$ were found to be exposed to eight PO (Table IV).

TABLE II - Frequency of Potentially Inappropriate Medication prescription according to the STOPP

\section{Potentially Inappropriate Medication}

Omeprazole - Proton pump inhibitor for peptic ulcer disease at full therapeutic dosage for $>8$ weeks

Diazepam - Long-term (i.e. $>1$ month) long-acting benzodiazepines

Haloperidol - Long-term (i.e.>1 month) neuroleptics as long-term hypnotics

Biperiden - Anticholinergics to treat extrapyramidal side-effects of neuroleptic medications

Chlorpromazine - Long-term (i.e. $>1$ month) neuroleptics as long-term hypnotics

Furosemide - Loop diuretic as first-line monotherapy for hypertension

Loperamide - Loperamide for treatment of diarrhoea of unknown cause

Alprazolam - Drug that adversely affect those prone to falls ( $\geq 1$ fall in past 3 months)

Bromazepam - Drug that adversely affect those prone to falls ( $\geq 1$ fall in past 3 months)

Carvedilol - Betablocker in combination with verapamil

Digoxin - Digoxin at a long-term dose $>125 \mu \mathrm{g} /$ day with impaired renal function

Etodolac - Non-steroidal anti-inflammatory drug with moderate-severe hypertension

Flurazepam - Long-term (i.e.>1 month), long-acting benzodiazepines

Glibenclamide - Glibenclamide with type 2 diabetes mellitus (risk of prolonged

hypoglycaemia)

Levomepromazine - Long-term (i.e. $>1$ month) neuroleptics as long-term hypnotics

Nifedipine - Calcium channel blockers with chronic constipation

Prednisone - Long-term corticosteroid as monotherapy for rheumatoid arthritis

Promethazine - Prolonged use of first generation antihistamines (risk of sedation and anticholinergic side effects)

Warfarin - Warfarin for first, uncomplicated deep venous thrombosis for longer than 6 months duration

$\begin{array}{cc}\text { Absolute } & \text { Relative } \\ \text { Frequency (n) } & \text { Frequency }(\%)\end{array}$

13

27.7

19.1

10.6

5

4.3

2

2

2

4.3

2

4.3

1

2.1

2.1

2.1

2.1

2.1

2.1

1

2.1

1

2.1

1

2.1

1

2.1

1

2.1

TOTAL 47

100

TABLE III - Association with PIM use analysis

Variables

Use of PIM - Beers' Criteria p value / OR (95\% CI)

Age groups (60-79 and $>79$ years)

Sex

Polypharmacy
$0.220 / 2.13(0.63-7.25)$

0.828 / 0.87 (0.26-2.97)

$0.019 / 4.49(1.24-16.26)$
Use of PIM - STOPP p value / OR (95\% CI)

$0.729 / 0.81(0.24-2.68)$

0.979 / 0.98 (0.29-3.31)

0.125 / $3.03(0.80-11.54)$ 
TABLE IV - Frequency of prescribing omissions

Prescribing Omission

Aspirin or clopidogrel with a documented history of atherosclerotic coronary, cerebral or peripheral disease in patients with sinus rhythm

Angiotensin-converting-enzyme inhibitor with chronic heart failure

Levodopa in idiopathic Parkinson's disease with definitive functional impairment and resultant disability

Bisphosphonates in patients taking maintenance oral corticosteroid therapy

Antiplatelet therapy in diabetes mellitus IF one or more co-existing major cardiovascular risk factors present

\begin{tabular}{cc}
$\begin{array}{c}\text { Absolute } \\
\text { Frequency (n) }\end{array}$ & $\begin{array}{c}\text { Relative } \\
\text { Frequency (\%) }\end{array}$ \\
\hline 3 & 37.5 \\
2 & 25.0 \\
1 & 12.5 \\
1 & 12.5 \\
1 & 12.5
\end{tabular}

\section{DISCUSSION}

Like in the present NH under study, hypertension was one of the most frequent diagnoses identified in other Brazilian NHs, and likewise in Italy, Spain and Norway (Correr et al., 2007; Danilow et al., 2007; Aguiar et al., 2008; Araújo et al., 2008; Gonçalves et al., 2008; Gutiérrez-Rodriguez, López Gaona, 2010; Halvorsen et $a l ., 2010)$. This portrays the escalating prevalence and mortality of cardiovascular diseases detected in Brazil and worldwide (IBGE, 2010).

The average number of drugs used $(4.3 \pm 2.7)$ detected in the present study was similar to the average number of drugs detected by Araújo et al. (2008) in another Brazilian NH (average $=4.8$ drugs/elderly). The average proved higher however, than those detected by Aguiar et al. (2008) and Correr et al. (2007) in two other Brazilian NHs (2.7 and 3.0 respectively), but lower than those detected in a Belgian NH by Azermai et al. (2011) (average $=7$ ), and by Gutierrez-Rodríguez \& LópezGaona (2010) and García-Gollarte et al. (2012) in Spanish NHs (averages of 6.3 and 6.5, respectively). Nonetheless, the higher the number of drugs used by the elderly, the higher the level of therapeutic complexity.

Mirroring other studies, the most prescribed drugs were those used to treat diseases of the nervous system and cardiovascular system (Castellar et al., 2007; Correr et al., 2007; Aguiar et al., 2008; Gutiérrez-Rodriguez, López Gaona, 2010). However, in most cases, the anatomical group "Cardiovascular System" tends to rank first, but this was not the case in the present study (Castellar et al., 2007; Correr et al., 2007; Danilow et al., 2007; Aguiar et al., 2008; Gutiérrez-Rodriguez, López Gaona, 2010). This may indicate excessive and irrational prescription of Nervous System acting drugs or inadequate diagnosis, since drugs classified as psycholeptics were the most prescribed. This group of drugs can reduce functionality and predispose the elderly to falls.

In the present study, the percentage of elderly using at least one PIM according to the Beers' Criteria (38.6\% of medication users) was high, indicating a possible lack of knowledge regarding the Beers' Criteria among prescribers, representing a higher rate than that detected by Aguiar et al. (2008) (32.9\%) and Varallo et al. (2012) $(29,2 \%)$ in Brazil.

The prevalence of PIM according to the Beers' Criteria among the prescribed drugs $(10.2 \%)$ was similar to the rate detected by Correr et al. (2007) in Apucarana - Brazil (13.5\%). In both these Brazilian studies, short acting nifedipine and amitriptyline were among the three most prescribed PIM, and in a study by Aguiar et al. (2008), amitriptyline was the most prescribed PIM. Diazepam, the most prescribed PIM in the present study, however, ranked only fourth in the studies by Correr et al. (2007) and Aguiar et al. (2008).

It is noteworthy that the three most prescribed PIM in the present study (diazepam, short acting nifedipine and amitriptyline) predispose the elderly to falls and fractures due to its pronounced sedation effect or increased risk of hypotension (Fick et al., 2003).

As for the identification of only one PIM considering diagnosis or conditions according to the Beers' Criteria, this is believed to be an underestimated indicator, due to the low quality of the patient charts in the studied institution.

Using the STOPP, however, the number of PIM detected was higher ( $n=47,24 \%$ of the prescribed drugs) and prescribed to a higher number of individuals $(n=28$, $63.6 \%$ of the medications users), despite the fact that STOPP contains less criteria for potentially inappropriate prescribing than the Beers' Criteria. No Brazilian studies with the use of the STOPP have been published, but international studies in NHs in Spain conducted by 
García-Gollarte et al. (2012) in Valencia and GutierrezRodríguez and López-Gaona (2010) in Asturia both detected greater prevalences than that detected in the present study (79\% and $71.4 \%$, respectively) (GutiérrezRodríguez, López-Gaona., 2010; García-Gollarte et al., 2012).

The three most prescribed PIMs according to the STOPP were: omeprazole, diazepam (also identified as the most prescribed PIM according to the Beers' Criteria in the present institution) and haloperidol. In the study conducted by García-Gollarte et al. (2012), the most prescribed PIM were also proton-pump inhibitors, benzodiazepines and antipsychotic drugs. Once again, the fact that the latter two drug groups predispose the elderly to falls and/or fractures draws attention (Fick et al., 2003).

As established by international studies, the present study also detected a statistically significant difference between the number of PIM identified by the Beers' Criteria and the STOPP, indicating that the latter tool has a higher potential for detecting unsafe prescription that can lead to drug-related adverse events (Hamilton, Gallagher, O'Mahony, 2009). However, no association between sex, age and use of PIM was encountered.

The prevalence of polypharmacy among the residents was high (37\%) and greater than the prevalence detected in other national studies (Castellar et al., 2007; Correr et al., 2007; Danilow et al., 2007; Aguiar et al., 2008; Gonçalves et al., 2008). Polypharmacy exposes the elderly to a higher risk of developing adverse events and, for this reason, should only be employed when the use of multiple drugs is indispensable (McLean, Le Couteur, 2004; Kostoff, Delafuente, 2006; Viktil et al., 2007; Hajjar, Cafiero, Hanlon, 2007). The association between polypharmacy and the use of PIM according to the Beers' Criteria detected in the present study corroborates with this fact. However, no association between polypharmacy and the use of PIM was identified according to the STOPP, unlike other studies conducted in hospitals (Gallagher et al., 2011).

The use of the START enabled the detection of PO for a substantial proportion of the studied population ( $17.4 \%$ of the elderly), however, it is believed that this value was underestimated due to problems concerning the documentation of health problems in the medical records/ charts and insufficient medical assistance.

To date, there are no studies in Brazil that show the use of the START, but the few international studies published show a higher frequency of PO among the elderly (52.4\% detected in Asturias and $74 \%$ in Valencia) (Gutiérrez-Rodríguez, López-Gaona, 2010; GarcíaGollarte et al., 2012).
The non-prescription of agents in a bid to reduce cardiovascular risk was the most common inappropriateness identified with the START (among six elderly). However, it is important to point out that the two patients with no angiotensin converting enzyme inhibitor (ACEI) in their prescriptions who had chronic heart failure used losartan (an angiotensin II antagonist that can substitute ACEI in cases where the patient develops adverse drug reactions to the latter).

Another PO detected was the need for prescription of antithrombotic agents to patients with diabetes and high cardiovascular risk $(\mathrm{n}=1)$. Nevertheless, in the light of recent knowledge, this practice has been questioned, since there are no studies showing that the use of aspirin reduces the risk of cardiovascular events in diabetic patients (Berger et al., 2011). Besides, the use of aspirin in low doses has been increasingly associated with the development of gastrointestinal bleeding, an adverse drug reaction especially dangerous in patients with diabetes mellitus, since this group tends to have an increased risk of presenting such events (up to 55\%) (Berger et al., 2011).

In contrast with the present study, in Valencia, Spain, the most commonly detected PO in NH were nonprescription of vitamin D, statins and aspirin (GarcíaGollarte et al., 2012).

\section{CONCLUSIONS}

Despite the small number of subjects, the present study allowed the diagnosis of a concerning drug utilization profile. Although the clinical outcomes of the drug therapy were not analyzed, the high number of inadequacies indicates a low level therapeutic decision process in the studied institution.

Thus, there is an evident need to implement strategies for improving geriatric prescription and clinical documentation. Pharmacists assuming the role of being co-responsible for geriatric drug therapy, as well as propagators of global knowledge in this area, represents a plausible alternative that could generate positive results, as described in the literature (RomanoLieber et al., 2002).

\section{REFERENCES}

AGUIAR, P.M.; LYRA-JÚNIOR, D.P.; SILVA, D.T.; MARQUES, T.C. Evaluation of pharmacotherapy on elderly residents of nursing homes in the north-east of Brazil. Lat. Am. J. Pharm., v.27, p.454-459, 2008. 
ARAÚJO, N.P.; BRITTO-FILHO, D.C.C.; SANTOS, F.L.L.; COSTA, R.V.; ZOCCOLI, T.L.V.; NOVAES, M.R.G. Socio-demographic and health aspects and the degree of satisfaction of the elderly institutionalized in the Federal District, Brazil. Rev. Ciênc. Med. Campinas, v.17, p.123$132,2008$.

AZERMAI, M.; ELSEVIERS, M.; PETROVIC, M.; VAN BORTEL, L.; STICHELE, R.V. Assessment of antipsychotic prescribing in Belgian nursing homes. Int. Psychogeriatr., v.23, p.1240-1248, 2011.

BERENSTEIN, C.K.; WAJNMAN, S. Population aging effects on inpatient care expenditures: a disaggregated analysis for two Brazilian metropolitan areas. Cad. Saúde Pública, v.24, p.2301-2313, 2008

BERGER, J.S.; LALA, A.; KRANTZ, M.J.; BAKER, G.S.; HIATT, W.R. Aspirin for the prevention of cardiovascular events in patients without clinical cardiovascular disease: a meta-analysis of randomized trials. Am. Heart J., v.162, p.115-124, 2011.

BRAUNSEIS, F.; DEUTSCH, T.; FRESE, T.; SANDHOLZER, $\mathrm{H}$. The risk for nursing home admission (NHA) did not change in ten years - a prospective cohort study with fiveyear follow-up. Arch. Gerontol. Geriatr., v.54, p.e63-e67, 2011 .

CAHIR, C.; FAHEY, T.; TEELING, M.; TELJEUR, C.; FEELY, J.; BENNETT, K. Potentially inappropriate prescribing and cost outcomes for older people: a national population study. Br. J. Clin. Pharmacol., v.69, p.543-552, 2010.

CASTELLAR, J.I.; KARNIKOWSKI, M.O.; VIANNA, L.G.; NÓBREGA, O.T. Study of the pharmacotherapy prescribed for older adults in a Brazilian long-term care facility. Acta Med. Port., v.20, p.97-105, 2007.

CORRER, C.J.; PONTAROLO, R.; FERREIRA, L.C.; BAPTISTÃO, S.A.M. Drug-related problems risks in patients of a geratric institution. Rev. Bras. Ciênc. Farm., v.43, p.55-62, 2007

DALLEUR, O.; SPINEWINE, A.; HENRARD, S.; LOSSEAU, C.; SPEYBROECK, N.; BOLAND, B. Inappropriate Prescribing and Related Hospital Admissions in Frail Older Persons According to the STOPP and START Criteria. Drugs Aging, v.29, p.829-837, 2012.
DANILOW, M.Z.; MOREIRA, A.C.S.; VILLELA, C.G.; BARRA, B.B.; NOVAES, M.R.C.G.; OLIVEIRA, M.P.F. Epidemiological, socialdemographic and psychosocial profile of institutionalized elders of the Federal District. Com. Ciênc. Saúde, v.18, p.9-16, 2007.

FICK, D.M.; COOPER, J.W.; WADE, W.; WALLER, J.L.; MACLEAN, R.; BEER, M.H. Updating the Beers' criteria for potentially inappropriate medication use in older adults: results of a US consensus panel of experts. Arch. Intern. Med., v.163, p.2716-2724, 2003.

GALLAGHER, P.; LANG, P.O.; CHERUBINI, A.; TOPINKOVÁ, E.; CRUZ-JENTOFT, A.; ERRASQUÍN, B.M. Prevalence of potentially inappropriate prescribing in an acutely ill population of older patients admitted to six European hospitals. Eur. J. Clin. Pharmacol., v.67, p.1175-1188, 2011.

GALLAGHER, P.; O’MAHONY, D. STOPP (Screening Tool of Older Persons' potentially inappropriate Prescriptions): application to acutely ill elderly patients and comparison with Beers'criteria. Age Ageing, v.37, p.673-679, 2008.

GARCÍA-GOLLARTE, F.; BALERIOLA-JÚLVEZ, J.; FERRERO-LÓPEZ, I.; CRUZ-JENTOFT, A.J. Inappropriate drug prescription at nursing home admission. J. Am. Med. Dir. Assoc., v.13, p.9-15, 2012.

GONÇALVES, L.G.; VIEIRA, S.T.; SIQUEIRA, F.V.; HALLAL, P.C. Prevalence of falls in institutionalized elderly in Rio Grande, Southern Brazil. Rev. Saúde Pública, v.45, p.938-945, 2008

GUTIÉRREZ RODRÍGUEZ, J.; LÓPEZ GAONA, V. Usefulness of a geriatric intervention program in the improvement of drug treatment for institutionalised patients. Rev. Esp. Geriatr. Gerontol., v.45, p.278-280, 2010.

HAJJAR, E.R.; CAFIERO, A.C.; HANLON, J.T. Polypharmacy in elderly patients. Am. J. Geriatr. Pharmacother., v.5, p.345-351, 2007.

HALVORSEN, K.H.; RUTHS, S.; GRANAS, A.G.; VIKTIL, K.K. Multidisciplinary intervention to identify and resolve drug-related problems in Norwegian nursing homes. Scand. J. Prim. Health Care, v.28, p.82-8, 2010.

HAMILTON, H.J.; GALLAGHER, P.F.; O’MAHONY, D. Inappropriate prescribing and adverse drug events in older people. BMC Geriatr., v.9, p.5, 2009. 
INSTITUTO BRASILEIRO DE GEOGRAFIA E ESTATÍSTICA. IBGE. Síntese de indicadores sociais uma análise das condições de vida da população brasileira (2010). Available at: <http://www.ibge.gov.br/home/ estatistica/populacao/condicaodevida/indicadoresminimos/ sinteseindicsociais2010/SIS_2010.pdf > . Accessed on: 10 Oct. 2012

KOSTOFF, R.N.; DELAFUENTE, J.C. The unknown impacts of combinations of large numbers of drugs. Drug Safety, v.29, p.183-185, 2006.

MCLEAN, A.J.; LE COUTEUR, D.G. Aging biology and geriatric clinical pharmacology. Pharmacol. Rev., v.56, p.163-184, 2004.

NAGENDRA VISHWAS, H.; HARUGERI, A.; PARTHASARATHI, G.; RAMESH, M. Potentially inappropriate medication use in Indian elderly: comparison of Beers'criteria and screening tool of older persons' potentially inappropriate prescriptions. Geriatr. Gerontol. Int., v.12, p.506-514, 2012.

O'MAHONY, D.O.; GALLAGHER, P.; RYAN, C.; BYRNE, S.; HAMILTON, H.; BARRY, P.; O'CONNOR, M.; KENNEDY, J. STOPP \& START criteria: a new approach to detecting potentially inappropriate prescribing in old age. Eur. Geariatr. Med., v.1, p.45-51, 2010.

ROMANO-LIEBER, N.S.; TEIXEIRA, J.J.; FARHAT, F.C.; RIBEIRO, E.; CROZATTI, M.T.L.; OLIVEIRA, G.S.A. A literature review on pharmacists' interventions in the use of medication by elderly patients. Cad. Saúde Pública., v.18, p.1499-1507, 2002.
RUGGIERO, C.; DELL'AQUILA, G.; GASPERINI, B.; ONDER, G.; LATTANZIO, F.; VOLPATO, S.; CORSONELLO, A.; MARALDI, C.; BERNABEI, R.; CHERUBINI, A. Potentially inappropriate drug prescriptions and risk of hospitalization among older, Italian, nursing home residents: the ULISSE project. Drugs Aging, v.27, p.747-758, 2010.

SCHRAMM, J.M.A.; OLIVEIRA, A.F.; LEITE, I.C.; VALENTE, J.G.; GADELHA, A.M.J.; PORTELA, M.C.; CAMPOS, M.R. Epidemiological transition and the study of burden of disease in Brazil. Ciênc. Saúde Coletiva, v.9, p.897-908, 2004.

VARALLO, F.R.; AMBIEL, I.S.S.; NANCI, L.O.; GALDURÓZ, J.C.F.; MASTROIANNI, P.C. Assessment of pharmacotherapeutic safety of medical prescriptions for elderly residents in a long-term care facility. Braz. J. Pharm. Sci., v.48, p.477-485, 2012.

VIKTIL, K.K.; BLIX, H.S.; MOGER, T.A.; REIKVAM, A. Polypharmacy as commonly defined is an indicator of limited value in the assessment of drug-related problems. Br. J. Clin. Pharmacol., v.63, p.187-195, 2007.

WORLD HEALTH ORGANIZATION. WHO. ATC/DDD system, Oslo, Norway (2011) WHO Collaborating Centre for Drug Statistics Methodology. Available at: <http://www. whocc.no/atc_ddd_index/>Accessed on: 24 Sept. 2012.

Received for publication on $12^{\text {th }}$ December 2013 Accepted for publication on $09^{\text {th }}$ Mach 2014 